\title{
Preparedness of Ghanaian Senior High School Instructors for Application of Online Learning in Social Studies Instruction amid the Covid-19 Pandemic
}

\author{
Iddrisu Bariham*, Samson Rosana Ondigi, Mueni Kiio \\ Department of Educational Communication \& Technology, School of Education, Kenyatta University, Nairobi, Kenya \\ E-mail: iddrisu.bariham@students.ku.ac.ke
}

Received: 29 July 2020; Revised: 15 October 2020; Accepted: 19 October 2020

\begin{abstract}
The COVID-19 pandemic brought about school shutdowns across the globe to prevent the spread of the virus. To avoid learning losses among students, online learning has been adopted by many countries including Ghana to continuously deliver instructions to learners. In Ghana, schools have been encouraged to reach out to students using virtual platforms but not without challenges. This research was therefore conducted in the Northern Region of Ghana to assess senior high schools teachers' preparedness for the integration of online learning in Social Studies teaching and learning. Three research questions were posed to guide the study. The data was collected using checklist which assessed schools digital readiness for virtual learning. Questionnaires, as the second instrument for data collection, were administered to 972 students and 84 Social Studies teachers from 12 secondary schools. The internal consistency of the questionnaires were established using Cronbach alpha formula which yielded $r=0.89$ for teachers and $r=0.73$ for the students. The study discovered that all schools had ICT laboratories and were connected to electric power for online learning. However, most classrooms were not connected to electricity to support virtual learning. Schools were not sufficiently equipped with ICT tools and lacked local ICT in education policy guidelines to guide E-learning. Teachers had content and pedagogical knowledge but lacked ICT technical skills do deliver online learning. Students' rate of integration of digital technology in Social Studies learning was low and ineffective. The study recommends connecting classrooms with electricity and internet, supply schools with adequate ICT tools, train and guide schools to design their local ICT in education policies, and organize periodic in-service training for teachers to build their capacity on how to integrate online learning in Social Studies teaching and learning to improve students learning outcomes.
\end{abstract}

Keywords: accessibility, authentic learning, equity, E-learning, online learning, social studies

\section{Introduction}

\subsection{Background to the study}

The COVID-19 pandemic did not only impact global health systems but also education. The health crisis brought about the need to practice social and physical distancing to be able to contain the spread of the virus. Schools have been shut down in many countries across the globe as part strategies to reduce the spread of the virus in the population. According to UNESCO (2020), over 1.2 billion learners were affected by the schools shutdowns. To curtail loss of

Copyright (C2020 Iddrisu Bariham, et al

DOI: https://doi.org/10.37256/ser.212021554

This is an open-access article distributed under a CC BY license

(Creative Commons Attribution 4.0 International License)

https://creativecommons.org/licenses/by/4.0/ 
learning, virtual or online learning, home schooling among others has been adopted by many countries across the globe including Ghana. Educational institutions no longer have a sole prerogative to determine where innovation comes from, how new knowledge is created and how it is applied. They no longer have the prerogative to determine how and the mode education delivery should take, whether direct face-to-face, distance learning or the online learning (Bradwell, 2009) quoted in (Oliver, 2020). Teachers and lecturers no longer have hegemony they once enjoyed, and this has implications for teaching and learning in schools.

As schools have been shut down globally, virtual learning became the most appropriate pedagogical strategy if teachers and lecturers are to reach out to their students in this fast paced digitized world affected by the pandemic. And whether post Covid-19 life will be same as pre-Covid-19 period is a subject of debate. But fact remain that out of this global crises spring opportunities for change. In crisis, change is not an option but a necessity. And, as Plato famously pointed out "Necessity is the mother of invention". As countries started easing their restrictions, blended learning became very popular among most educational institutions. Blended learning have given various names such as "technology mediated instruction", "hybrid learning", "mixed-mode instruction", and "web-enhanced instruction". Wikipedia (2020) defines blended learning as instructional approach that integrate online learning with traditional faceto-face classroom teaching and learning. Blended learning has been categorized into 12 major strands, namely; lab rotational blended learning, remote blended learning, station rotation blended learning, flip classroom blended learning, flex blended learning, project based blended learning, individual rotational blended learning, inside-out blended learning, self-directed blended learning, supplemental blended learning, out-in blended learning, and mastery-based blended learning (Tech Thought, 2020).

Ghana's educational system is fraught with myriad of problems even before the onset of the pandemic. The Education Sector Analysis (ESA) cited in the Ghana Education Sector Medium-Term Strategy, 2018-2021 diagnosed weaknesses in the Ghana's education system to include inequities in access, participation, and poor learning outcomes, as well as lack of capacity of the system to address the shortcomings. These challenges can be resolved as educational content across various disciplines are now available online and freely accessible to learners and educators regardless of their location and background. Social Studies curriculum places emphasis on patriotism, tolerance, honesty, accountability, inclusivity, and diversity. Digital education will not only accomplish the above objectives but can also address educational quality and inequality issues as all learners irrespective of their background can learn from best scholars and teachers across the world. However, the digital divide is still an obstacle to the effective utilization of virtual learning by most schools. Most learners especially from poor households lack access to computers, internet and other digital tools for online learning. Global Education Monitoring Report (2019) discovered that worldwide, $52 \%$ of primary schools and $67 \%$ of secondary schools were not connected to electricity in 2016 . Online Learning African Report (2014, as cited in Tanye, 2017) reported that efforts to apply technology for learning in Africa have experienced $49 \%$ failure. Several interventions have been implemented to ensure schools are equipped with appropriate digital infrastructure to enhance online learning. However, the data on Technological Pedagogical Content Knowledge and competencies of senior high school Social Studies teachers to be able to apply virtual learning has been relatively patchy. Questions on the level of secondary schools readiness with the internet connectivity with other digital resources suitable for E-learning remained unanswered.

\subsection{Problem statement}

Effective online teaching, learning and assessment in schools require a robust school digital infrastructure, teachers and students computer skills and suitable administrative support to flourish. Critical components of these digital infrastructure include TV sets, radio, reliable internet, enough computers, projectors, laptops, relevant E-learning content, smart boards, among others. In addition, we have to examine the availability of relevant teacher professional development programmes for teachers and heads of schools. But in Ghana, digital application divide exists and will continue to exist between communities and schools, concerning those who have access to and they are using technology for online learning and those who apply cloud technology for passive content consumption.

The COVID-19 pandemic presented an opportunity for government to outline specific policies to support E-learning especially at the pre-tertiary level of education. In the private sector, most of the private TV and radio stations started their own online learning platforms to complement the governmental effort of providing inclusive and quality education for all and lifelong learning in the midst of the pandemic. However, some experts raised issues with the quality of the 
content, inclusivity and whether the content conformed to the national curriculum, and social values of the country. Besides, the existing digital divide in the country excluded many children from rural and under privileged backgrounds from benefiting from such educational interventions. Empirical data from the previous studies discovered that some senior high schools in Ghana do not have access to and are not applying online learning in Social Studies teaching and learning as required. It was against this background that the study was conducted to investigate the level of senior high schools and teachers' and students readiness for the application of online learning in Social Studies teaching and learning in the midst of the pandemic.

\subsection{Research questions}

The following questions were posed and examined by the present study:

What is the level of senior high schools preparedness in terms of digital infrastructure to support online learning?

How prepared are teachers and students to pedagogically apply technology to deliver online Social Studies instruction?

To what extent do students apply technology during Social Studies learning?

\section{Review of related literature}

\subsection{Meaning and rationale for the inclusion of social studies in school curriculum}

There are many and varied definitions of Social Studies as there are Social Studies educators. National Council for Social Studies in an attempt to define Social Studies pointed out that "the field of Social Studies is so caught up in ambiguity, inconsistency and contradiction that it represents a complex educational enigma......", and if Social Studies is what the scholars in the field perceived it to be, then it is a schizophrenic bastard child" (Barr et al., 1977). The most influential and convincing of these was those by Barr et al. (1977), who sum up the various positions of social studies curriculum into three main strands, namely; Social Studies as Citizenship Education (that inculcate loyalty, social values, and desirable attitudes to serve society), Social Studies as amalgamation of the social sciences (to provide general knowledge and skills for an informed man), and Social Studies as a reflective inquiry (aim at creating a citizen who can identify problems, formulate hypothesis, collect data, analyze the data, and draw conclusions based on the data). In Ghana, there is consensus among Social Studies educators that Social Studies is an issue-centered subject. The subject integrates concepts and principles from the various social sciences and applies them to address societal challenges. The subject exposes students to the persistent contemporary issues affecting national development and attitudes, values, knowledge, and skills to resolve those problems. The goal of Social Studies is Citizenship Education which seeks to imbibe in learners critical and creative thinking skills for both identifying social problems and taking civic actions towards solving them, and training learners on their civic rights and responsibilities for nation building. But without sufficient training, teachers' efforts to promote tolerance and critical attitudes in learners may be inadequate or counterproductive (GEM Report, 2019).

It is important that Social Studies teachers understand and appreciate what is involved in implementing the prescribed curriculum using the blended learning approach. Curriculum implementation demands putting into practice the officially prescribed courses of study, syllabuses and the appropriate content (Urevbu, 1985). The process involves supporting students to acquire relevant knowledge, skills or experiences. Ghana's human capital needs to be harnessed for sustainable development, and education has a critical role to play. School curriculum implementation whether viewed from the lenses of social re-constructivist, humanistic, systematic or academic perspectives cannot take place in a vacuum but should be woven around the interests and needs of the learner and the society. Learning should focus on the experiences of learners. University of Zimbabwe study (Quashigah et al., 2014) extrapolated that curriculum delivery takes place as the learner acquires the planned or intended experiences, skills, relevant knowledge, principles and attitudes that are geared towards enabling the student to function effectively in a changing society. The adoption and implementation of Social Studies curriculum should be situated in the social constructivist approach where learners work collaboratively during instructions to construct and create new knowledge based on their own experiences while instructors offer scaffolding supported by technology. Curricula should help instructors to utilize pedagogical 
approaches that value diversity in learning and helps educational institutions to accommodate multiple perspectives (GEM Report, 2019).

Meaningful Social Studies learning must be problem-centered rather than content-oriented. Ghana's problems are many and varied. For instance, amidst rampaging COVID-19 pandemic, Ghana is confronted with myriad of internal social, political and economic challenges such cynicism, suspicion and mistrust, superstitious believes, vote buying by political players, tribal politics, pull him down syndrome, bribery and corruption, frequent use of insults and hate speech by the political actors, and abuse of political power and incumbency. Political thuggery often supported and perpetuated by the political elites is rife in the country. There is growing insecurity and violent crimes in the country. The unending youth unemployment has made Ghanaian youth vulnerable and open them up for recruitment by politicians for all kinds of dirty jobs including serving as political vigilantes or thugs who often unleash violence on political opponents with impunity. A survey by CDD-Ghana in 2016 discovered that 54\% of participants believed that Ghanaian politicians were highly likely to employ violence during the 2016 general elections (US Department of State, 2016). Recently, concerns have been raised about the abundance of weapons in the system. Kofi Annan International Peacekeeping Training Center (KIPTC) reported that there were nearly 1 million unregistered weapons in circulation in Ghana (US Department of State, 2016). Social Studies exposes students to these problems of human survival in society, and then equips them with relevant knowledge, appropriate skills, and desirable attitudes and values to deal with such problems. Social Studies inculcate in learners critical thinking, hard work, self-reliance, attitude of continued learning, empathy, honesty, ethics and integrity, tolerance and the appreciation of human dignity, open-mindedness, national consciousness and patriotism, obedience, loyalty, critical judgement, constructive criticism, power of imagination and resourcefulness, accountability, respect for the rights of others, respect for the law, and decision making informed by data. With these, students will be equipped with arbitration, negotiation, mediation and reconciliation as strategies for conflicts resolution and not violence.

\subsection{Adoption of online learning in social studies instruction}

Online learning has been given several names, namely; virtual learning, E-learning, Computer Based Instruction, Computer Assisted Instruction, among others. Online learning whether synchronous or asynchronous require educational technology platforms to operate. Educational technology can be grouped into two, namely; operational technologies and pedagogical technologies. Pedagogical technologies is further divided into two, namely; programbased technologies and tool-based technologies. Program-based technologies are created for pedagogical purposes with already made content delivered using algorithm-supported instruction. Examples include computer educational games, online personalized learning tutorials, computer drills and practice, hyperstudio, computer simulations, authorware, among others (Gao et al., 2019). Tool-based on the other hand are not produced purposely for education but can also be applied in various fields such as business, trade, manufacturing, agriculture, health, transport and communication among others. Examples include smartboards, internet, Microsoft Office, PowerPoint, social media, television, video, radio, and the like. Online learning facilitates authentic learning in Social Studies. Learning is a personal interpretation of issues around us, therefore, individual differences must be taken into account when designing Social Studies online learning programmes to facilitate authentic learning among students.

Virtual field trips for example create a cost-effective means of exposing students to places and people around the world. They are equally helpful when they precede actual field trips. The virtual trip delivered by video, YouTube, Facebook and the like can expose Social Studies students to scenes and sounds associated with historical, political, social, economic, geographical, and religious sites they have never visited in person. However, there are limitations to electronic field trips when used in isolation. Poorly prepared learners can aimlessly surf the Web, achieving only a cursory overview of information (Berson \& Balyta, 2004). Virtual field trips may also lose their educational value when focused more on the entertainment aspects. Also, learning is enhanced by challenge and inhibited by threats, hence, online learning programmes including virtual field trips should present students with realistic problems in society to challenge them to think critically for solutions to those problems. By so doing, authentic learning will take place. Experience including mistakes offer a basis for learning activities, hence learners who commit errors must be supported and not punished.

One critical component of Social Studies education involves the study of principles, historical facts, geographical features and their relevance, sustainable use of environmental resources, conflicts and conflicts resolution among others. 
Computer tutorials and drills and practice can be used to teach those concepts. Findings from a survey by Higgins and Boone as reported in Berson (1996) discovered small, but little improvement in secondary school students' achievement and attitude towards Social Studies when hypermedia, drills and practice instructions were delivered. Further study is required to evaluate the impact of online learning on the taxonomic level of students. However, further study is required to evaluate the impact of online learning on the taxonomic level of students. The substantial growth and development of the telecommunication sector over the years has created online services, social media, WebPages, software, E-mail, and global information systems that can be used to support E-learning. App Anne found that the world's smartphone users downloaded over 200 billion mobile apps in 2019, invested almost 120 billion US dollars on apps and their related purchases over a year ago. Social media apps can stimulate interaction among people from different ethnicities, cultures and faiths and have a positive effect on students learning and open-mindedness (GEM Report, 2019). The internet, for instance, offers an environment within which millions of people engage in the production and sharing of information and can be used to support online learning. A national survey conducted by the USA in 2006 concluded that over $90 \%$ of schools had access to the internet to support online learning. However, the situation in Africa and for that matter Ghana is the opposite, but there is hope for the future.

Another important platform that can be used to support E-learning in Social Studies is multimedia. Multimedia mixes texts, graphics, sounds and pictures in information delivery and can be used by Social Studies instructors to support students' online learning. The audio, visuals, and audiovisual symbols from radio, videos, and television can assist students to gain deeper understanding and appreciation of concepts, develop higher order thinking skills and facilitate cooperative learning among Social Studies students. Effective teaching employs a variety of learning approaches. Video lessons integrated in PowerPoints slides, for instance, inspire students to learn, facilitate active participation of students in learning, and foster the acquisition of higher order thinking skills such as analysis, synthesis, and evaluation (Mai \& Ken, 2003). Online learning can assist learners acquire the $21^{\text {st }}$ century skills, stimulate selfregulated learning, critical thinking, and complex problem solving skills. Digital learning can also inject inclusion, efficiency, and innovation in the teaching and learning of Social Studies. For instance, Nafham 'We Understand' is a free online education website established in 2012 which produces video content suitable for primary and secondary school students, inspires learners to learn, supports teachers and parents to produce videos, which add up to the over 10,000 videos produced so far. These educational videos cover more than 75\% of Egyptian national curriculum (GEM Report, 2019). In Jordan and Lebanon, the International Rescue Committee (IRC) designed a project called Vroom Programme which adopted a model designed for poor households in the USA. It deliverer animation and videos using Facebook and WhatsApp, to offer parenting in the form of advice and games, skills sessions and home visits. Results from impact assessment discovered positives results associated with the intervention as quoted in (GEM Report, 2019).

\subsection{Preparedness of schools to support online learning}

Literature on the preparedness of schools for online learning yielded high levels of readiness for educational institutions in the developed countries and low level of preparedness for those in the developing world especially in Africa. Wilson et al. (2015) whose research in Kenya secondary schools preparedness for online learning implementation found that $77.8 \%$ of male teachers reported lack of in-service training on technology integration; inadequate ICT experts to offer teachers support and to service computers; and absence of governmental funding to support online learning in schools. The study was however silent on female instructors' readiness. However, the findings implies poor readiness of the schools to utilize virtual platforms to deliver quality education. Similarly, Ngatia (2015) in his study in Kenya reported similar findings when he discovered that secondary schools' preparedness for virtual learning was poor because instructors were not sufficiently trained on how to pedagogically integrate technology in their instructions. It seems digital illiteracy is still high worldwide. Only 1 in 3 in upper middle income nations can copy and attach files to emails, increasing to $58 \%$ and $70 \%$ respectively in higher income countries (GEM Report, 2019). In Indonesia, Mahdum et al. (2019) discovered that although instructors had positive perceptions towards online learning, they faced challenges such as lack of technical and pedagogical expertise and insufficient digital infrastructure in schools.

In Ghana, the Ministry of Education rolled out several interventions to improve the quality of secondary education. For instance, data from the Ministry of Education Medium Term Expenditure revealed that iBox education portals and solar panels were supplied to 125 secondary schools, online learning multimedia laboratories set up in 242 secondary schools, and 8,738 white boards installed to replace chalk board in those schools. Plans are far advanced to extend Wi-Fi 
to all secondary schools in the country to promote virtual learning. At the tertiary level, some universities in Ghana are members of the largest E-learning network in Africa dubbed African Virtual University (AVU) established in 1997 with headquarters in Nairobi, Kenya. Ghana is also a member of the African Council for Distance Education Quality Assurance and Accreditation Agency (ACDE QAAA) with headquarters in Kenya, charged with responsibility of capacity building, institutional audits, programmes reviews, accreditation of institutions and courses, and interpretation of credit transfers (ACDE QAAA, 2011). The University of Ghana for example established a Local Area Network (LAN) covering all the campuses. The LAN accommodates the university internet and internet access, Learning Management System (LMS), students records, hosts the university email, website, ICT laboratories, a library catalog hosting different books, periodicals, articles, and other relevant educational resources cited in (Adjabeng, 2017).

Governments have a role to play in achieving sustainable quality and affordable online learning in educational institutions. Accreditation of online learning programmes should be accompanied by a strong supervisory and monitoring body to ensure that the institutions go by the agreed quality standards. In this regard, the Ministry of Education in Ghana has set up a Center for National Distance Learning and Open Schooling (CENDLOS) to supervise open and distance learning programmes at the tertiary level of education in the country. The center successfully produced and distributed E-learning content across different subjects to junior high schools and senior high schools in the country (Tanye, 2017). Questions on the sustainability and relevance of those E-learning content and whether teachers at that level have been adequately prepared to pedagogically use technology for online learning remain unanswered.

Schools preparedness for online learning can be categorized into four, namely; schools digital readiness, instructors' digital and pedagogical competencies, learners' digital readiness, and national and local systems and policies. Schools ICT preparedness entails the extent of internet and electricity connectivity, availability of sufficient ICT tools, level of administrative support, and the availability of ICT supporting staff. Teachers' preparedness involves the Technological Pedagogical Content Knowledge of teachers, their access to computers and the internet, and the level of support and encouragement from peers and school management. Students' preparedness involves access to computers and the internet at home and in school, students ICT skills, level of support from home and school, gadgets ownership, among others. Systems and policies are local and national ICT in education policies, ministerial directives, among others. In this study, Shihomeka (2020) virtual learning environment framework for online learning strategy formulation was adopted. Senior high schools teachers' readiness became the independent variable for the study whereas the application of online learning in Social Studies education was the dependent variable. Shihomeka further outlined eight strategic framework for E-learning strategy formulation, namely; schools readiness SWOT analysis; teachers' digital and pedagogical preparedness; learners characteristics; externalities on E-learning; design and formulate online learning strategy; implementation of the E-learning strategy; monitoring, evaluation, and learning; and dissemination of the results. In constructivist learning, knowledge is constructed from experience, and therefore, online learning programmes must be designed based on the needs and experiences of the learner.

Internet connectivity serves as a backbone within which the implementation of online learning can occur. Globally, the total number of internet users as at January 2020 stood at 4.54 billion people, 7 percent increase (298 million new users) compared to the previous year. Presently, 5.19 billion people use mobile phones worldwide, 2.4 percent increase (124 million new users) over the year 2019 (Global Digital Insight, 2020). However, the amount of time people spend online differs from country to country. As at January 2020, 3.2 billion people globally were not connected to the internet, 27 percent of these people ( 870 million unconnected people) came from sub-Saharan Africa. Age and gender plays critical roles in determining the levels of access to and use of the internet in many countries. Recent data from ITU indicates that women are highly likely to be unconnected to the internet compared to men. The digital gender divide also exists in latest social media access and usage data. In Ghana, the internet penetration rate was 48 percent, with 14.76 million internet users, social media penetration rate was 20 percent, with 6 million social media users as at January 2020 (Digital Ghana, 2020). Almost 39.97 million mobile phone connections were recorded in Ghana by early 2020. This presents a huge potential for online learning adoption by educational institutions in the country. Again, learning should be situated in a realistic context, as a result, assessment should be integrated in all learning activities and not a separate task. Online learning strategies such as computer tutorials deliver instruction with immediate feedback as learners' progress with learning activities.

Implementation of virtual learning requires support from the telecom companies who control internet connectivity. 
In this regard, some multinational telecom giants who control internet connections have initiated some online learning projects in some countries in Africa as part of their social responsibilities. For example, according to Vodafone Foundation (2019), the Instant Network School, a joint initiative involving Vodafone and the UN High Commission for Refugees (UNHCR), supported over 40,000 learners, 600 instructors in 20 primary and secondary schools in Tanzania, Kenya, Democratic Republic of Congo, and South Sudan, and planned to reach over 500,000 refugee children by 2025. Under the project, schools in deprived and remote communities were connected with the internet using satellite or mobile networks, electricity supplied through backup generators and solar-powered batteries, and flexible digital content and other online learning resources to support virtual learning. Vodafone Foundation study (2019) reported that preliminary results from impact evaluation of the project in Kenya discovered a 3 percent jump in students' attendance and a $36 \%$ improvement in their participation for primary school certificate examinations. However, in spite of these positive results, a challenge from such initiatives is sustainability and how to connect preloaded and online resources with the curricula of the beneficiary countries. Telecom companies led those projects and have a tendency to place more emphasis on technical aspects of the installation of the service than the pedagogical application of the content. Nevertheless, new sets of platforms, for instance RACHEL are creating Learning Management Systems (LMS) and curriculum alignment options to address similar challenges. Cost-benefits analysis should be conducted before signing up to rapid scaling-up of digitization of learning, private teaching or the involvement of multinationals co-operations in education (GEM Report, 2019).

\section{Materials and methods}

The study adopted embedded mixed research design that utilized questionnaires and checklist as instruments for data collection. The questionnaires were consisted of 10 closed ended items each to gather data on teachers' level of preparedness for the application of online learning in Social Studies instruction. A checklist was used to assess schools digital readiness for online learning. The rationale for the adoption of embedded mixed research design was to enable the researchers answer different research questions that requires different answers using different types of datasets. Secondary school Social Studies teachers and students were the target population for the study. As at the time of data collection, there were 55 senior high schools in the previous Northern Region (comprising current Northern Region, and the two newly created North East and Savana regions). Generally, 12 schools were randomly sampled representing $(21.8 \%)$ of the target population. Out of the target population of 7,786 form three students enrolled in the sampled schools, 972 students were randomly chosen for the study based on Yamane formula for sample size determination. From the 107 Social Studies teachers, 84 teachers representing $(78.5 \%)$ were randomly selected to participate in the study. This exceeded a proposal by Cohen et al. (2011) which extrapolated that a sample of 20-30\% is acceptable in surveys when dealing with a smaller population. The questionnaires and a checklist were the main instruments used to collect the data for this study. The questionnaires were constructed on a 5 points Likert scale comprising 10 closed ended items each to determine the rate of preparedness of the senior high school teacher and students for the implementation of online learning in Social Studies teaching and learning. A checklist with 10 closed ended items was employed to amass data on the level of schools digital infrastructure readiness for the application of online learning in Social Studies instruction. To test the research instrument, piloting was conducted in two schools within the study area but which were not part of those sampled for the study. The reliability of the questionnaire and the checklist were established using Cronbach alpha. The reliability of the questionnaire for Social Studies teachers yielded an alpha of $\mathrm{r}=$ 0.89 and that of the students produced an alpha of $r=0.73$ which were within acceptable standard and were employed to collect the data for the study. The data from the study were analyzed using the Statistical Package for Social Sciences (SPSS) version 22.

\subsection{Ethical consideration}

Research ethics are as relevant and critical in research as they are in other fields of human behavior. As a result, research ethics were observed during the study. Permission to conduct the study was obtained from the Northern Regional Director of education and school heads before the data collection in sampled schools. Respondents' rights were upheld throughout the study. Participants were not compelled nor materially induced to participate in the research. They rather participated voluntarily with rights to pull out at any time. Informed consent was sought from all the respondents 
so that they participated voluntarily. Anonymization and pseudonymization were used to protect the identity of the participants who took part in the study. Information for the respondents were kept confidential and applied for research purposes only. Finally, the author declared no conflict of interest. There were no funding sponsors who had a role in the design of the study; in the data collection, analyses, or interpretation of data; in deciding whether or not to publish the final report.

\section{Discussion of results and findings}

To answer research question 1: "What is the level of senior high schools readiness in terms of digital infrastructure to support online learning?" a checklist was used to evaluate schools digital infrastructure results of which is presented in Table 1.

Table 1. Results from evaluation of senior high schools ICT infrastructure

\begin{tabular}{ccc}
\hline Level of Digital Infrastructure Readiness & Frequency (YES) & Percentage (\%) \\
\hline Institution has sufficient computers & 0 & 0.0 \\
Institution has ICT lab for online learning & 12 & 100 \\
Location computers and other ICT tools are accessible to all & 12 & 100 \\
School has reliable internet to enhance E-learning & 1 & 8.3 \\
School has electricity to support online learning & 12 & 100 \\
School has smartboards for online learning & 1 & 8.3 \\
Institution has a generator for power back-up & 0 & 0.0 \\
All classrooms are connected to electricity & 4 & 33.3 \\
Institution has TV sets, DVD players and digital content & 4 & 33.3 \\
School has ICT policy to direct online learning & 0 & 0.0 \\
\hline
\end{tabular}

Results from Table 1, indicates that all the 12 sampled schools (100\%) had functioning ICT laboratories, and locations of those labs were accessible to all learners and instructors for online learning. This serves as an opportunity to effectively lunch online learning in schools. All schools were also connected with electricity to facilitate virtual learning which confirms (Government of Ghana Mid-Year Review and Supplementary Estimates, 2020) which concluded that access to the electricity in the country stood at $84 \%$, which constituted the second highest in Sub-Saharan Africa. However, only 4 schools reported their classrooms were connected to electricity for online learning in class. The rest restricted virtual learning to ICT labs. Online learning must not be limited to the ICT laboratories but solid infrastructure should be in place to expand the innovation across schools and even homes. Also, although current internet penetration in the country stood at 48\% with 14.76 million internet users and 6 million social media users as at January 2020, all the 12 schools confirmed they did not have sufficient computer to support application of technology during instructions, and only 1 school (8.3\%) had internet and smart board respectively for E-learning. This could partly be attributed to the expensive nature of the internet data in the country fueled by internal taxes. However, recent reduction of tax on the internet data by the government from 9\% to 5\% last September, 2020 could serve a big boast to E-learning. All the sampled schools did not have school internal ICT policies to direct online learning.

To answer research question 2: "How prepared are instructors and students to pedagogically apply technology for online Social Studies instruction?" a five points Likert scale questionnaire was given to the teachers to complete with KEY: SD = Strongly Disagree, $\mathrm{D}=$ Disagree, $\mathrm{U}=$ Undecided, A = Agree, and SA = Strongly Agree, results of which is computed in Table 2. 
Table 2. Social studies teachers technological and pedagogical content knowledge

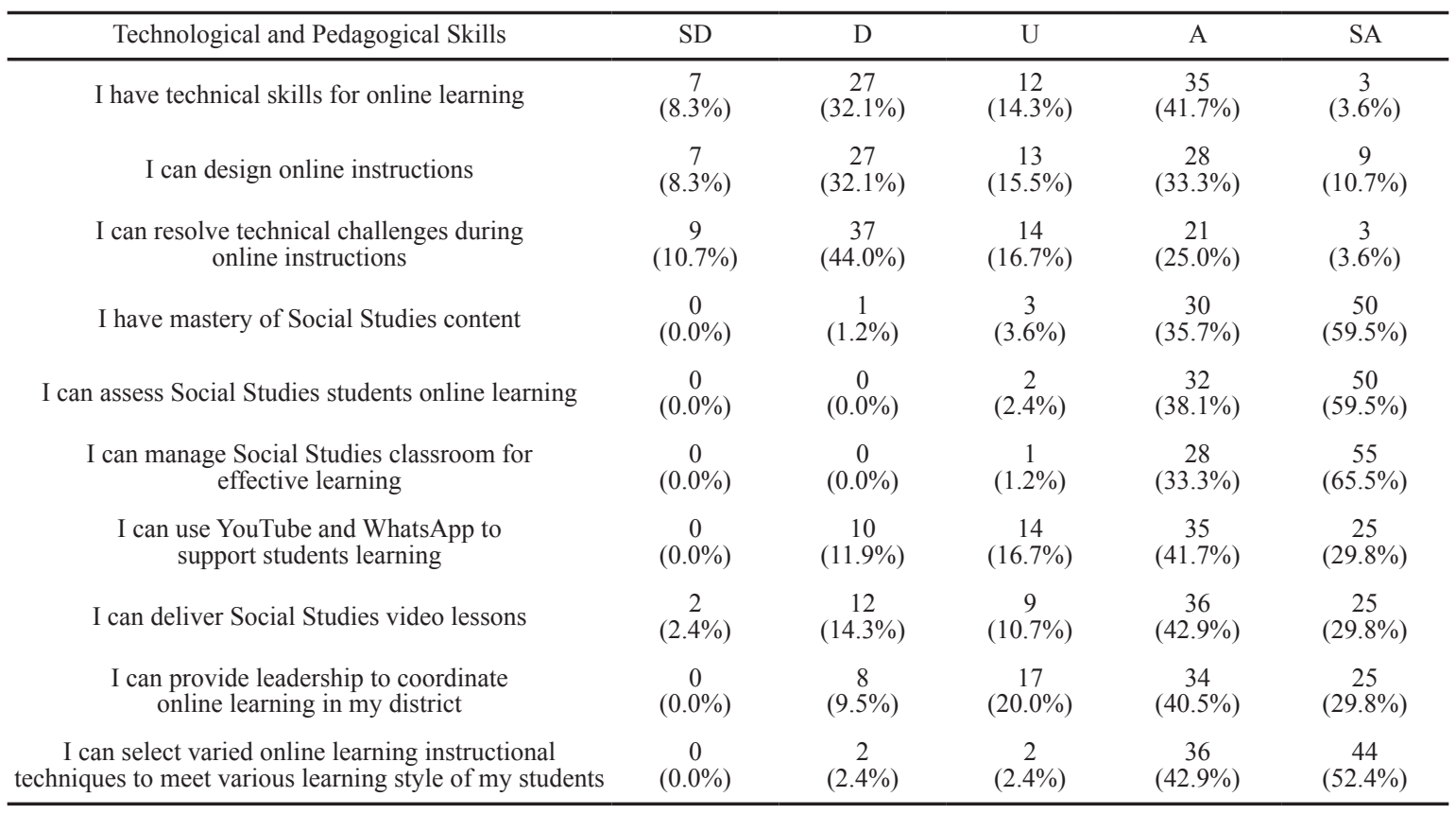

Table 2 results indicated that 34 teachers $(8.3 \%+32.1 \%)=40.4 \%$ did not have sufficient technical skills for online learning, 34 teachers $(8.3 \%+32.1 \%)=40.4 \%$ responded they could not design online instruction in Social Studies education. Additionally, 46 instructors $(10.7 \%+44.0 \%)=54.7 \%$ indicated they could not solve their own technical challenges during online learning. This implies that a significant number of teachers lacked technical skills to effectively deliver online instruction during Social Studies education. In terms of pedagogical skills, 82 teachers $(38.1 \%+59.5 \%)$ $=97.6 \%$ responded that they could assess online learning, 83 instructors $(33.3 \%+65.5 \%)=98.8 \%$ indicated that they could manage Social Studies online learning environment, and 80 teachers $(42.9 \%+52.4 \%)=95.3 \%$ indicated they could select different online learning strategies to meet the varied learning styles of students. This implies that the majority of the teachers had pedagogical competencies to implement online learning in Social Studies education. The results contradicts those from Mensah (2020) whose literature review on pedagogical competencies of Ghanaian Social Studies teachers cited inadequate knowledge in process skills, avoiding controversial issues, limited knowledge on the meaning of concepts, and shallow knowledge of content as barriers to Social Studies education in Ghana. In terms of content Knowledge, 80 teachers $(35.7 \%+59.5 \%)=95.2 \%$ responded that they have adequate subject matter knowledge in Social Studies to implement online learning. This results again contradicts a study by (Mensah, 2020) which cited shallow knowledge of content as barriers to Social Studies education in Ghana. Efforts should rather be geared towards building technical competencies of teachers to enable them successfully integrate online learning in their instruction.

To answer the research query 3: "To what extent do students apply technology during Social Studies learning?" an analysis of the level at which students incorporate online learning strategies into learning of Social Studies was measured results of which are presented in Table 3 . 
Table 3. The extent to which students apply technology during social studies learning

\begin{tabular}{|c|c|c|c|c|c|}
\hline Online Learning & Not at all & Rarely & Once a week & $\begin{array}{l}\text { Several times } \\
\text { per week }\end{array}$ & Daily \\
\hline Use of computer tutorials & $\begin{array}{c}870 \\
(89.5 \%)\end{array}$ & $\begin{array}{c}27 \\
(2.8 \%)\end{array}$ & $\begin{array}{c}49 \\
(5.0 \%)\end{array}$ & $\begin{array}{c}18 \\
(1.9 \%)\end{array}$ & $\begin{array}{c}8 \\
(0.8 \%)\end{array}$ \\
\hline Use of instructional stimulations & $\begin{array}{c}613 \\
(63.1 \%)\end{array}$ & $\begin{array}{c}155 \\
(15.9 \%)\end{array}$ & $\begin{array}{c}82 \\
(8.4 \%)\end{array}$ & $\begin{array}{c}55 \\
(5.7 \%)\end{array}$ & $\begin{array}{c}67 \\
(6.9 \%)\end{array}$ \\
\hline Use of educational videos & $\begin{array}{c}873 \\
(89.8 \%)\end{array}$ & $\begin{array}{c}54 \\
(5.6 \%)\end{array}$ & $\begin{array}{c}24 \\
(2.5 \%)\end{array}$ & $\begin{array}{c}14 \\
(1.4 \%)\end{array}$ & $\begin{array}{c}7 \\
(0.7 \%)\end{array}$ \\
\hline Use of social media such as YouTube and WhatsApp & $\begin{array}{c}866 \\
(89.1 \%)\end{array}$ & $\begin{array}{c}46 \\
(4.7 \%)\end{array}$ & $\begin{array}{c}24 \\
(2.5 \%)\end{array}$ & $\begin{array}{c}16 \\
(1.6 \%)\end{array}$ & $\begin{array}{c}20 \\
(2.1 \%)\end{array}$ \\
\hline Use of mobile phones & $\begin{array}{c}782 \\
(80.5 \%)\end{array}$ & $\begin{array}{c}83 \\
(8.5 \%)\end{array}$ & $\begin{array}{c}56 \\
(5.8 \%)\end{array}$ & $\begin{array}{c}31 \\
(1.6 \%)\end{array}$ & $\begin{array}{c}20 \\
(2.1 \%)\end{array}$ \\
\hline Use of computer intelligent tutoring systems in learning & $\begin{array}{c}664 \\
(68.3 \%)\end{array}$ & $\begin{array}{c}124 \\
(12.8 \%)\end{array}$ & $\begin{array}{c}64 \\
(6.6 \%)\end{array}$ & $\begin{array}{c}41 \\
(4.2 \%)\end{array}$ & $\begin{array}{c}79 \\
(8.1 \%)\end{array}$ \\
\hline Use of computer problem solving approach & $\begin{array}{c}737 \\
(75.8 \%)\end{array}$ & $\begin{array}{c}89 \\
(9.2 \%)\end{array}$ & $\begin{array}{c}63 \\
(6.5 \%)\end{array}$ & $\begin{array}{c}38 \\
(3.9 \%)\end{array}$ & $\begin{array}{c}45 \\
(4.6 \%)\end{array}$ \\
\hline $\begin{array}{l}\text { Learning from PowerPoint presentations combined } \\
\text { with animations }\end{array}$ & $\begin{array}{c}808 \\
(83.1 \%)\end{array}$ & $\begin{array}{c}77 \\
(7.9 \%)\end{array}$ & $\begin{array}{c}41 \\
(4.2 \%)\end{array}$ & $\begin{array}{c}26 \\
(2.7 \%)\end{array}$ & $\begin{array}{c}20 \\
(2.1 \%)\end{array}$ \\
\hline
\end{tabular}

Data from Table 3 show that, 870 students (89.5\%) indicated they never used computer tutorials during Social Studies learning, 613 respondents (63.1\%) agreed they never used computer simulations at all during learning of Social Studies, 785 student $(80.8 \%)$ reported they never used educational CDs, and as many as 873 students $(89.8 \%)$ never used videos in Social Studies learning. Again, in spite of the fact that as at January, 2020, there were 6 million social media users in Ghana (Digital Ghana, 2020), 866 participants (89.1\%) never ever used social media platforms like WhatsApp and YouTube during Social Studies learning. This could be attributed to the digital divide in the country. Again, although as at January 2020, there were 39.97 million mobile phone connections in Ghana (Digital Ghana, 2020), as many as 782 students (80.58\%) did not use mobile phones for learning. This could be blamed partly to the Ghana Education Service policy which prohibits senior high school students' access to phones on campuses. This is the time to take a second look at the policy. In terms of application of computer problem solving approach during Social Studies learning, 737 participants (75.8\%) reported they never used such a strategy, and as many as 808 students (83.1\%) indicated they were not using PowerPoint presentation combined with animations during Social Studies learning. The above results implies that the use of digital technology during learning of Social Studies by students was extremely low and ineffective. This could be attributed to several factors including poor students ICT skills, lack of access to computers, limited teachers technological and pedagogical competencies, lack of access to internet at home and in schools, among others. This findings reconciled with those from (Natia \& Al-hassan, 2015) whose research on application of ICT in Ghanaian Basic Schools cited teachers limited technical competencies, lack of internet, absence of electric power and insufficient number of computers as factors responsible for low uptake of online learning among basic schools in the country.

\section{Conclusions}

In line with the findings, the following conclusions have been drawn. All sampled schools had ICT laboratories which were accessible to instructors and learners to facilitate online learning. However, having access to ICT laboratories alone cannot guarantee the effective application of virtual learning in schools. Teachers and students need to be trained sharpen their ICT skills and be conversant about their roles to be able to make a smooth transition from the 
traditional face-to-face teaching to online learning. Kenyatta University in Kenyatta demonstrated this best practice by first designing and implementing training of teaching staff and students before the commencement of blended learning adopted by the university. However, access to funding to implement these training could be lacking which serve as a threat to the successful implementation of online learning in schools. Additionally, all sampled schools were connected to electric power to enhance E-learning. However, classrooms of most of the schools were not connected to electric power to promote online learning. It came out that to prevent students from charging their phones which are not allowed in senior high schools, the majority of the schools deliberately discounted electricity supply in classrooms. This limits teachers and students ability to integrate technology in teaching and learning in classrooms. The $21^{\text {st }}$ century classroom should have access to electricity, and well equipped with relevant instructional resources to deliver authentic learning experiences to students. Plans are far advance by the government of Ghana to remove this barrier to pave the way for the application of digital technology in teaching and learning in schools across the country.

The majority of the schools were not equipped with adequate TV sets, DVD players, projectors, smart boards, and relevant digital content to support online learning. Schools did not also have local ICT in education policy guidelines to direct the implementation of online learning to suit their peculiar contexts. Insufficient digital infrastructure has been cited by previous as one of the most critical barrier to online learning in Ghanaian schools over the last decade. Presently, visibility studies have been conducted across all public senior high schools in the country to inform government to be able to supply the schools with the needed digital infrastructure to support virtual and blended learning in schools. However, citing legal basis, the private senior high have been left out of this initiative by the government. Finally, the majority of teachers had subject matter knowledge and pedagogical competencies to effectively deliver online learning in Social Studies education, but a significant number of teachers lacked technical skills and competencies for online learning. This explains why the application of digital technology during learning of Social Studies by senior high school students was very low and ineffective. More training and capacity building is needed to pedagogically prepare the teachers to be able to integrate online learning in their instructions to improve students learning outcomes. Although the majority of teachers have competences to use social media platforms to support online learning, the majority of the students did not used social media platforms like WhatsApp, and YouTube to support their learning. This is partly due to limited access to smartphones and the internet. Government of Ghana should supply senior high school teachers and students with highly subsidized smartphones connected to the internet to support online learning in schools.

\section{Recommendations}

Based on the conclusions, the following recommendations have been made:

i. The Ministry of Education in collaboration with the Ghana Education Service should release funds for the connection of electricity to all classrooms of senior high schools in the country to facilitate online learning activities.

ii. The Government of Ghana in collaboration with the Ministry of Education should supply all senior high schools with TV sets, DVD players, projectors, smart boards, relevant E-learning content, and reliable internet to enhance online learning.

iii. The Ghana Education Service should train and guide all senior high schools to develop their local ICT in education policies to guide the implementation of online learning activities in schools.

iv. The Ghana Education Service should periodically organized in-service training Progammes to build the capacity of senior high school teachers and students on how to use virtual learning to improve students learning outcomes in line with the SDG 4.

v. Government of Ghana in partnership with the Ministry of Education should supply all senior high school students with tablets connected with free Wi-Fi to facilitate students' online learning activities to improve their learning outcomes. 


\section{Acknowledgements}

This study is part of a Doctoral thesis which focused on preparedness of senior high schools for integration of technology in Social Studies education in the Northern Region of Ghana. The research team wish to express our appreciation to Professor Kisilu Kombo, Dean, School of Education, Kenyatta University, Kenya, and Dr. Adelheid Marie Bwire, Chairperson, Department of Educational Communication \& Technology, Kenyatta University, Kenya for providing a conducive learning environment within which this project was successfully executed. Our second appreciation goes to heads of sampled schools in Ghana for granting us permission to conduct the research, and to all sampled Social Studies teachers and students for participating in the study with integrity and honesty, and to Columbia Global Centers and Harvard Graduate School of Education for face-to-face and online training. Our final appreciation goes to the two research assistants in Ghana, namely; Mohammed Kamaldeen and Jacob Nluki for playing varied roles during the fieldwork stage of this study. All errors remain the authors' own.

\section{References}

Adjabeng, S. (2017). The status challenges of online distance education programs in post-secondary institutions in Ghana (Doctoral Thesis Report). University of Texas, USA. https://eric.ed.gov/?id=ED584081.

Barr, R. D., Barth, J. L., \& Shermis, S. S. (1977). Defining the Social Studies. United States Publisher Arlington, VA: National Council for the Social Studies.

Bearson, M., \& Balyta, P. (2004). Technological thinking and practice in the Social Studies: Transcending the tumultuous adolescence of reform. Journal of Computing in Teacher Education, 20(4). https://www.tandfonline.com/doi/abs/1 0.1080/10402454.2004.10784498.

Berson, M. J. (1996). Effectiveness of computer technology in the social studies: A review of the Literature. Journal of Research on Computing in Education, 2(4), 486-499.

Bradwell, P. (2009). The Edgeless University: Why Higher Education must embrace technology. http://hdl.voced.edu. $\mathrm{au} / 10707 / 90069$.

Cohen, L., Manion, L., \& Morrison, K. (2011). Research Methods in Education (6th ed.). Routledge Publishers (part of the Taylor \& Francis group), Oxford, UK.

Gao, P. P., Nagel, A., \& Biedermann, H. (2019, August 23). Categorization of educational technologies as related to pedagogical practices. Pedagogy in Basic and Higher Education-Current Developments and Challenges. https:// www.intechopen.com/books/pedagogy-in-basic-and-higher-education-current-developments-and-challenges/ categorization-of-educational-technologies-as-related-to-pedagogical-practices.

Global Education Monitoring Report. (2019). Migration, Displacement and Education: Building Bridges, Not Walls. France: UNESCO. http://gem-report-2019.unesco.org/.

Government of Ghana Budget. (2020, July 23). Mid-year review of the budget statement and economic policy of the government of Ghana \& supplementary estimate for the 2020 financial year. Accra: Ministry of Finance. https:// www.mofep.gov.gh/news-and-events/2020-mid-year-review-of-the-budget-statement-and-economy-policy.

Mai, N., \& Ken Neo., T.K. (2003, October 10th). Developing a student-centered learning environment in The Malaysian classroom-A multimedia learning experience. Turkish Online Journal of Educational Technology. http://tojet.net/ articles/v4i2/423.pdf.

Mahdum, M., Hadriana, H., \& Safriyanti, M. (2019). Exploring teachers perceptions and motivations to ICT use in learning activities in Indonesia. Journal of Information Technology Education: Research, 18, 293-317.

Mensah, R. O. (2020). Pedagogical analysis of teaching social studies: Am empirical literature review. Journal of Humanities and Social Sciences, 3(2), 66-76.

Natia, J. A., \& Al-hassan, S. (2015). Promoting teaching and learning in Ghanaian basic schools through ICT. International Journal of Education and Development using Information and Communication Technology (IJEDICT), 11(2), 113-125.

Ngatia, P. K. (2015). Preparedness of public secondary schools on the use of information communication technology in teaching and learning in Mukurweini, Nyeri County-Kenya. Unpublished Maters Thesis: Kenyatta University, Kenya. https://ir-library.ku.ac.ke/bitstream/handle/123456789/14446/Preparedness\%20of\%20public\%20 secondary $\% 20$ schools......pdf? sequence=1\&isAllowed $=\mathrm{y}$.

Oliver, M. (2020). Viral knowledge: Disciplinarity during a pandemic. [Keynote presentation], Kaleidoscope 2020, Cambridge UK, May $28^{\text {th }} 2020$. https://ioe.academia.edu/MartinOliver. 
Quashigah, A. Y., Dake, G. Y., Bekoe, S. O., Eshun, I., \& Bordoh, A. (2014). Evaluation of Colleges of Education (COE) social studies curriculum vis-à-vis the Junior High School (JHS) social studies curriculum in Ghana. European Journal of Training and Development Studies, 1(2), 1-13.

Shihomeka, S. P. (2020). Shihomeka's virtual learning environment frame work: E-Teaching and online Learning strategy formulation process flow. Manuscript submitted for publication. https://www.pressreader.com/namibia/newera/20200728/281646782467446.

Tanye, H. A. (2017). Quality E-learning in distance learning: Benefits and Implications for national E-learning policy in Ghana. International Journal of Multicultural and Multireligious Understanding, 4(3), 1-11.

US Department of State. (2016). Low-level violence likely during Ghanaian elections. Diplomatic security services: Research \& Information Support Center (RISC).

Vodafone Foundation. (2019). Instant Network Schools: a connected education Programme. Newbury: Vodafone Foundation.

Wikkipedia, Free Encyclopedia. (2020, October 26th). https://en.wikipedia.org/wiki/Blended_learning.

Wilson, S., Lydiah, N., \& Pachomius, W. (2015). School's preparedness in information communication technology integration in teaching and learning in public secondary schools. A case of Kieni east sub-county Nyeri County, Kenya. IOSR Journal of Humanities and Social Science (IOSR JHSS), 20(2), 90-99. 